\title{
Penal humanitarianism? Sovereign power in an era of mass migration ${ }^{1}$
}

\author{
Mary Bosworth, University of Oxford and Monash University
}

\begin{abstract}
Since creating the 'Returns and Reintegration Fund' in 2008, the British government has financed a variety of initiatives around the world under the rubric of "managing migration" which have blurred the boundaries between migration control and punishment. This article documents and explores overlapping case studies in Nigeria and Jamaica where the UK has funded prison building programs, mandatory prisoner transfer agreements, prison training programs and resettlement assistance for deportees. These initiatives demonstrate in quite concrete ways a series of interconnections between criminal justice and migration control that are both novel and, in their postcolonial location, familiar. In their ties to international development and foreign policy they also illuminate how humanitarianism allows penal power to move beyond the nation state. In so doing, these overseas programs raise important questions about our understanding of punishment and its application.
\end{abstract}

\section{Keywords}

Punishment, mass migration, sovereignty, Jamaica, Nigeria, penal humanitarianism, colonialism

\section{Introduction}

When people are sent to prison in the UK we should do everything we can to make sure that if they're foreign nationals, they are sent back to their country to serve their sentence in a foreign prison. And I'm taking action in Government to say look we have strong relationships with all of the countries where these people come from. Many are coming from Jamaica, many from Nigeria, many from other countries in Asia. We should be using all of the influence we have to sign prisoner transfer agreements with those countries. Even if necessary frankly helping them to build prisons in their own country so we can send the prisoners home. (David Cameron, 25 April 2013 in Cardiff, UK, as reported by Doyle in the Daily Mail)

In 2012, the British government funded the construction of a new wing and guard tower in Kirikiri prison in Lagos, Nigeria. They also contributed money to assist in the training of prison officers and the purchase of new equipment for the Nigerian Prison Service (Iroegbu and Oyedele, 2012). That year, in Jamaica, the British High Commission released a DVD, entitled "Coming home to Jamaica",

\footnotetext{
1 This research was funded by my 2012 - 2017 ERC Starter grant 313362, 'Subjectivity, Identity and Penal Power'. I would like to thank Ana Aliverti, Vanessa Barker, Richard and Michal Bosworth, Ben Bowling, Emma Kaufman Michael Light, Sarah Turnbull and all the participants in the March 2016 symposium at the Centre for Criminology, University of Oxford on Criminal Justice Adjudication in an Age of Migration for their helpful comments and feedback on earlier drafts.
} 
alongside a revised booklet with the same title aimed at those removed or deported from Britain. Through the Returns and Reintegration Fund (RRF) they supported the fledgling National Organisation for Deported Migrants (NODM) while also paying for a variety of prison programs throughout the island from pastry courses for young female offenders to chicken farming in an all-male sex offender facility. Three years later, in 2015, the British Prime Minister David Cameron announced plans, while visiting Kingston, to invest $£ 25$ million in a new prison as part of an agreement with the Jamaican Parliament for a new mandatory prisoner transfer agreement (PTA).

These examples reveal an increasing policy trend located at the intersection of criminal justice, migration control, and foreign policy, in which the penal state radiates well beyond the confines of the nation. Emblematic of Britain's devotion to the tactics of "soft power" (House of Lords, 2013) and humanitarianism, these policies and practices also link into much older pathways evident in the origins of the buildings and criminal justice systems invested in today, many of which date to the colonial era (Saleh-Hanna, 2008). Similar programs with equivalent postcolonial ties can be found elsewhere and in engagements with other parts of the criminal justice system. Ben Bowling (2010), for instance, has written a detailed account of the investment in policing and security in the Caribbean by a variety of countries, while legal scholars have described the Australian investment offshore in detention sites in Nauru and Manus Island (e.g., Dauvergne, 2016). Supranational organisations like the United Nations and the European Union also fund and operate initiatives through pooled funds like the European police organisation FRONTEX (Aas and Gundhus, 2015). This article focuses on British policies.

Criminologists have begun to explore the effects of globalization and increased global mobility within the walls of prisons and other carceral institutions (see, for example, Kaufman, 2015; Bosworth, 2014; Hasselberg, 2016; Warr, 2016; Bhui, 2016; Krutschnitt et al, 2013). In a related field, a small number have paid attention to the geographical spread of penal power (Aas, 2013; Brotherton and Barrios, 2011). This article seeks to conjoin these areas of scholarship by reflecting on the implications and effects of overseas sites of British involvement and humanitarian aid for our understanding of sovereignty and punishment.

\section{Penal power and sovereignty}

It is widely accepted that punitive practices and carceral institutions are inherently contradictory. Punishment has always had a variety of contradictory goals. From claims that it rehabilitates or deters, is a deserved response to wrongdoing or merely incapacitation, its impact and justification is never straightforward (O'Malley, 1999).

On the one hand, punishment is a clear expression of state power. The extent to which the government may interfere in the lives of those who break the law is significantly higher than it is for those who do not. On the other hand, penal power is always precarious. Punishment, David Garland (1996) argued twenty years ago, thus reveals the limits of sovereign power. No matter how hard it tries, the government cannot eradicate crime. Penal practices remain inherently contested. They are supported for and by some while simultaneously eschewed for and by others. 
In the literature on punishment, attempts have been made to shift the debate in light of other changes to state sovereignty. The impact of globalisation and mass migration has not gone unnoticed, particularly among scholars in the nascent field of border criminology (Aas, 2014; Bosworth, 2012; Barker, 2013; Kaufman, 2015). For these authors, penal practices are changing, and our understanding of what counts as punishment needs to shift as well. Therefore, while there remain good analytical and empirical reasons to retain a focus on the criminal process of specific jurisdictions (Zedner, 2013; Duff, 2010), we also need to take a wider perspective (Aliverti, 2016). Practices outside the criminal justice system not only feel punitive to those subject to them, but they have similar justifications and effects. These administrative powers also shape people's lives in spaces and places well beyond the prison (Kaufman and Weiss, 2015; Golash-Boza, 2015).

Globalisation and migration are not the only relevant factors in the shifting nature of state power (Hannah-Moffat and Lynch, 2012). The government increasingly shares responsibility for crime control and punishment with individual offenders and the private sector. Governing at a distance, it retains the right and the duty to punish, while divesting itself of some of the messier aspects of enforcing order. In this way, a host of new kinds of courts, in which guilt is already admitted before the trial begins, have sprung up, while access to parole has narrowed. The involvement of the private and the voluntary sector across the criminal justice arena has also expanded (Jones and Newburn, 2002; Tomczak, 2014). From private prisons to partnerships with NGOs, under neoliberal hegemony, the state rarely operates alone in the administration of justice. In some institutions, like immigration detention centres, it may be hard to find it at all, having handed over responsibility for daily operations to others (Bosworth, 2014).

Foreign offenders are subject to sovereign power in particular ways (Kaufman, 2015). A criminal sentence is likely to trigger administrative powers of detention and deportation, profoundly shaping the experiences of incarceration and adding significant new consequences of this group (Warr, 2016; Bhui, 2007). It engenders new levels and sites of governance (Kaufman and Bosworth, 2014). A criminal offence committed in one jurisdiction may cause foreigners to fall under the purview of a second sovereign state: their country of citizenship.

All these matters play out each day across police stations, courts, prisons, and immigration detention centres. They also can be found much further afield, in so-called sending countries, beyond the jurisdiction where the original crime or punishment occurred. In those places, which are the focus of this article, the state takes yet another form, partnering not only with the foreign government, but also with the private sector, international agencies and local and international NGOs. The British government, in these external sites, also works with itself as the Home Office, the Ministry of Justice, and the Department of International Development (DFID) act through and with the Foreign \& Commonwealth Office (FCO) in order to secure the border against past and future offenders.

While these practices resonate with other, more familiar forms of penal power and concerns about risk and security, in their focus on foreign citizens and in their location offshore, they take new forms and are animated by distinct 
goals and rhetoric. The targets of British offshore strategies are not destined for reintegration in the UK. Funding and expertise is used to expel and keep them out. In order to return them and make them stay, these strategies must not only set up a process of expulsion, but also make the case about where certain people 'belong'. In so doing, they do not simply alter the constraints and logic of the criminal process, by subjecting foreigners to differential outcomes for their crimes than citizens, but they designate people to a place (Barker, in press).

In 'bordering' and 'reordering' (Aas, 2013; 2014; Barker, 2013), the state cannot rely solely on rhetoric and practices of security or punishment. Instead, they persuade countries to accept their returning citizens through investment and policy exchange. As border control and punishment merge, in other words, penal power and humanitarianism increasingly work together (Agier, 2011). The sections below map the origins of these developments in UK criminal justice and migration policies before turning to Nigeria and Jamaica. ${ }^{2}$

\section{Securing the border at home and abroad}

Currently there are 9300 foreign nationals serving prison sentences in England and Wales (HMIP, 2015). Accounting for $11 \%$ of the total incarcerated population, this sum has stabilized over the past few years, after expanding rapidly in the first decade of the $21^{\text {st }}$ century. Until 2006, foreign offenders rarely figured in public debate about crime or punishment. Yet, that year, following extensive coverage in the British tabloid press, then Home Secretary Charles Clark lost his job when it was discovered that, over the previous decade, 1000 foreign prisoners had been released without being considered for deportation. The political and media outcry over this relatively small number successfully presented foreign national prisoners as deserving harsher treatment by mobilizing familiar and more novel concerns about risk and belonging (Kaufman, 2012, 2013, 2015; Bhui, 2007). Fears about economic migration merged seamlessly with narratives about terrorism and radicalisation, constructing foreign national offenders as fundamentally unwelcome and always, already, potentially dangerous.

Such concerns and ways of thinking about foreign offenders have had a profound impact on legislation and policy, radically shifting how the courts and the prison service deal with them (Bosworth, 2007; Bhui, 2007; Kaufman, 2015; Warr, 2016). From the "the forgotten ones" (Prison Reform Trust, 2004), foreign offenders appear ubiquitous. Relabelled as a security threat, they have been excluded from various work and drug treatment programs in prison; considered an escape threat, they are rarely sent to open conditions. In both cases, their immigration status trumps their conviction and rehabilitative needs.

In addition to constraining the experiences of foreign nationals during their sentence, the British government has sought to eject as many of them as possible through voluntary prisoner transfer agreements (Home Office, 1998;

\footnotetext{
${ }^{2}$ As with much government policy, matters in this area are fluid. In March 2016, many of the tasks formerly undertaken by the RRF, were absorbed into a new conflict, security and stability fund (CSSF), under the strategic direction of the National Security Council. This development expanded the pool of government departments and agencies working together, to include the Ministry of Defense, thereby further entrenching the securitization of migration issues. This article covers the period before this new arrangement.
} 
see also Van Zyl Smit and Mulgrew, 2014). “The United Kingdom,” legal scholar, Jamil Mujuzi (2012: 381) notes,

can now exchange offenders with several countries on three bases: on the basis of the bilateral agreement between the UK and the relevant country, and on the basis of the Council of Europe Convention on the Transfer of Sentenced Persons which has been ratified not only by European countries but also countries outside Europe, and on the basis of the Scheme for the Transfer of Convicted Offenders within the Commonwealth which has been ratified by a few Commonwealth countries.

Those who agree to go home can apply for financial assistance under various forms of Assisted Voluntary Return (AVR) schemes (Poppleton and Rice, 2010). They also benefit from a sentence reduction of up to 270 days (Evans, 2010).

"The political dream of assisted return schemes," political theorist William Walters observes (2016: 438), "is to provide a sufficient level of material inducement such that the migrant places themselves on the plane, without the need for guards, restraints or any spectacle of enforcement." Yet, in the UK at least, few men or women take up these offers. Although official statistics are hard to find, in 2014 The Telegraph reported scornfully that, "just 17 foreign criminals have been sent home to serve their sentences under a treaty that was intended to clear Britain's jails of mainland European offenders" (Holehouse, 2014). "The EU Prisoner Transfer Agreement was signed by Britain and 17 other member states and came into force in December 2011," the article goes on. "Since then three Belgians, a Latvian, a Maltese and 12 Dutch prisoners have been sent home. Ten were guilty of drugs offences, three of sexual offences, one for causing death by dangerous driving and one for a stabbing" (Holehouse, 2014). The Commonwealth Scheme for the Transfer of Convicted Offenders has been even less effective, the Minister for Prisons recently acknowledged, resulting in the transfer of just one person (Wright, 2014).

Reflecting the utility (and reach) of administrative powers (Thomas, 2011; Costello, 2015), deportation of foreign offenders post-sentence has been considerably more effective than PTAs. Since the UK Borders Act 2007, all nonEEA offenders sentenced to 12 months, or whose sentences over the past five years add up to that amount, face automatic deportation, unless there are human rights prohibitions preventing it. EEA citizens are harder to deport, although they too maybe expelled if they are serious or prolific offenders (Bosworth, 2011; Home Office, 2015a). All foreign offenders, even those without a custodial sentence, should be considered for deportation.

Official figures suggest such powers have had some effect, although not as much, a 2015 report from the House of Commons Committee of Public Accounts makes clear, as some politicians had hoped:

The number of foreign national offenders removed from the UK peaked at 5,613 in 2008-09 and has not matched that level since. Indeed the figure fell to 4,539 in 2011-12 and despite an improvement to 5,097 in 2013-14 remains below the 2008-09 levels. This is despite the fact that the number of staff working 
on foreign national offender cases has risen from less than 100 in 2006 to over 900 in 2014. (House of Commons, 2015: 5)

The House of Commons (2015: 5) report notes, rather impatiently, that the Home Office attributes "the lack of progress ... to the inherent complexity of the system and overall policy framework and an increase in the number of appeals by foreign national offenders." Such appeals are likely to lessen, as the Immigration Act 2014 and the Immigration Bill 2015 have targeted a number of perceived barriers to deportation, removing the right of many foreign offenders to an in-country appeal, and making it more difficult for them to access human rights protections related to family life. Nonetheless, at the time of writing, despite considerable investment in the bureaucracy of deportation, the number forced out of the country has not increased.

Given the low uptake of voluntary transfer agreements, the cost of imprisoning foreigners, and the difficulties of enforcing deportation, the Britain government has, alongside others in the EU, sought to forcibly repatriate serving prisoners by creating a series of mandatory prisoner transfer agreements. Whereas "most of the prisoner transfer agreements to which the UK is a party require the consent of sentenced person concerned as well as that of both States involved," a recent memorandum explains, "international prisoner transfer agreements are moving away from the idea that prisoners should have to consent to transfer" (Wright, 2014: 2). The Additional Protocol to the Council of Europe Convention on the Transfer of Sentenced Persons 1997 "provides for the transfer of prisoners without their consent where they would otherwise be deported at the end of the sentence" (Wright, 2014: 2). Ratified by the UK in 2009 , the logic of this protocol can also be found in the Framework Decision on the transfer of prisoners between Member States of the EU that was adopted by the UK government on 28 November 2008 and came into force on 5 December 2011. Such policies, as their names suggest, operate at the state level, bypassing the individual. Once the Treaty is in place, both states are expected, under normal circumstances, to accept their citizens put forward for return by their partner. ${ }^{3}$ Britain currently has compulsory transfer agreements with Albania, Ghana, Nigeria, Somaliland, Libya, and Rwanda.

With some notable exceptions, criminologists and legal scholars have paid scant attention to these developments. Yet, prisoner transfer agreements and deportation are now an everyday part of criminal justice systems around the world (van Zyl Smit and Mulgrew, 2012; Mujuzi, 2012). While deportation is not, in itself, a form of punishment because it is an administrative action, a deportation order may be handed down as part of a criminal sentence. Along with PTAs, deportation is also referenced in debates and policies about border control alongside statistics of annual migration rates (Chorley, 2013), refugees, and asylum seekers. In these examples the reach of penal power is made clear.

In addition to pursuing bilateral agreements and entrenching their enhanced powers of expulsion, the British government invests in numerous schemes abroad designed to stop those they expel from coming back. These same programs also seek to dissuade others who might otherwise be tempted to travel. Some overseas projects focus on incarcerated populations, others on

\footnotetext{
3 It is, in other words, a reciprocal arrangement.
} 
deportees and still others more broadly on the poor and vulnerable. Administered and often funded by the FCO, these local initiatives are run by a range of voluntary sector organisations as well as by the criminal justice system. In Nigeria the British Council delivers much of the program material under a multifaceted project entitled "Justice 4 All". 4

Part of a more general trend within the international donor community towards the "justice sector" (Pichon, 2005), many of the UK schemes are financed by the Returns and Reintegration Fund. This reserve, Lord Davies of Oldham explains in a written response to a Parliamentary question from Baroness Northover in the House of Lords on 13 March 2009,

aims to increase the number of failed asylum seekers and foreign national prisoners who are returned to their country of origin and helps to tackle illegal immigration to the UK. It delivers projects in overseas countries which face challenges in accepting back and reintegrating their nationals; provides rehabilitation and reintegration assistance to individuals who return voluntarily; and helps improve the process of removal from the UK.

The fund began on 1 April 2008 and is a pooled fund, comprising the Foreign and Commonwealth Office (FCO), Department for International Development, Ministry of Justice and UK Borders Agency financial resources and expertise, managed by the FCO.

Projects are identified with overseas governments and/or by government departments which are party to the fund. At the end of 2008 , we were financing or had in development 83 projects in a wide range of countries to which the UK is returning people. (Written answers, Lords Hansard, 13 Mar 2009: Column WA286)

Unlike the voluntary return schemes that offer financial incentives to individuals to return, the RRF pays and trains overseas state and local governments, agencies, and NGOs to make people stay. It was from this fund, the BBC reported in 2012, that the British government spent $£ 3 \mathrm{~m}$ to "improve improve prisons in Jamaica and Nigeria in order to send inmates in UK jails back to their home countries" (BBC, 2012). The sections below set out these two case studies in more detail.

\section{Nigeria}

According to the FCO, there are currently between 800,000 and 3 million Nigerians resident in the UK (FCO, 2015). A former colony, Nigeria retains a number of economic, cultural, and legal ties to Britain. Part of the Commonwealth, it is one of the most populous and diverse states in Africa. It is also oil-rich. Governed by a powerful and wealthy elite, Nigeria continues to struggle with inter-ethnic violence, corruption, terrorism, and extensive poverty

\footnotetext{
${ }^{4}$ See British Council website for further information: https://www.britishcouncil.org/partner/track-record/justice-for-all-programme
} 
(Home Office, 2015b).

Nigerians make up one of the largest groups of foreign national prisoners in England and Wales. They also account for a considerable proportion of the population held in immigration detention. For many years, the British government has sought to return these individuals, to free up space and reduce the cost of running prisons and immigration removal centres. It has also attempted to reduce (irregular) migration from Nigeria. In such attempts, targeted at its former colonial subjects, the British government draws on the combined force and expertise of DFID, the FCO, and, increasingly, the Ministry of Justice and the Home Office. In 2009, DFID summarized the situation:

HMG [Her Majesty's Government] migration policy in Nigeria has a number of strands including return of end of sentence Foreign National Prisoners (FNPs) and Failed Asylum Seekers, as well as building the capacity of the Nigerian authorities to manage migration effectively and to deter irregular migration. Another priority is the high numbers of Nigerian Foreign National Prisoners (FNPs) in UK jails - the second highest foreign national population. In line with the Prime Minister's policy the UK is seeking to agree a without-consent prisoner transfer agreement with Nigeria to provide a mechanism for transfer and reintegration of prisoners to serve out their sentences in Nigeria. (DFID, 2009: Paragraph 129) ${ }^{5}$

Although DFID has no statutory duty to reduce migration, it "recognises that its programmes may have spin off benefits in helping to address factors which may encourage individuals to migrate, such as poverty, conflict and bad governance" (DFID, 2009: paragraph 130).

Notwithstanding considerable investment, Britain's attempts to rid itself of serving prisoners and irregular migrants from its former colony, without disrupting economic ties with the current regime, have been only partially successful. It has had to overcome a number of legal, practical and political barriers at home and in Nigeria. In some areas it has been more successful than others.

For many years, there were simply insufficient constitutional safeguards within the Nigerian criminal justice system to allow Britain to forcibly repatriate their citizens. More narrowly, the Nigerian 1963 Prisons Act and the Transfer of Convicted Offenders Act (Enactment and Enforcement) Act 1988 had to be amended, as they "provided that the offender could only be transferred with his or her consent and that such consent had to be verified by the administering

\footnotetext{
${ }^{5}$ The following paragraph from the 2009 report notes: "In view of the high priority of HMG migration objectives in Nigeria, DFID has seconded a 'Return and Reintegration Advisor' to work with the High Commission on these issues. The advisor is paid for by UKBA [UK Border Agency] and their primary function is to advise on designing relevant programmes for the non-ODA crossWhitehall Return and Reintegration Fund. The advisor works in a cross government team, using DFID technical and programming experience to support cross HMG objectives. Programme activity has focused on identifying capacity constraints in the Nigerian Prison Service (NPS) and considering ways in which HMG can support the NPS to carry out its functions more effectively and be better equipped to reintegrate returned FNPs. The team has also considered how to put in place preventative measures to stem irregular migration from Nigeria to the UK" (DFID, 2009: paragraph 130).
} 
country to ensure that it was given voluntarily" (Mujuzi, 2012: 385; see also Iroegbu and Oyedele, 2012). Finally, conditions in Nigerian prisons were so dire that Britain risked court interventions at home and from Strasbourg if they tried to return people forcibly (Mujuzi, 2012; Jefferson, 2005).

The first issue was resolved in September 2011 when, as part of a series of changes, the Federal Parliament amended large parts of Section IV of the 1999 Nigerian constitution, concerning Fundamental Rights, to reflect international human rights norms. Section 34(a) specified an entitlement "to respect for the dignity of human person, and accordingly - no person shall be subjected to torture or to inhuman or degrading treatment," while section 35(1) and (2) protected the right to personal liberty and to silence. Other amendments promised transparency for the grounds of arrest or detention, (section 35(3)), prompt criminal charging (34(4)(5) and compensation for ill treatment (35(6)). Section 36(4-6) established the requirements of a "fair hearing" in "a reasonable time" in "a court of law" and, under normal circumstances, in public. People were to be presumed innocent until proven guilty. ${ }^{6}$

One month later, after extensive lobbying from the British government, the Nigerian Parliament also removed "the consent requirement [for prisoner transfers] from their national law" (Mujuzi, 2012: 386). From this point onwards, the legal barriers to repatriation appeared to have been resolved. In the third and final area to do with prison conditions, however, matters have stalled.

Overwhelming evidence suggest that Nigerian prisons remain violent, overcrowded, filthy and dangerous (Omale, 2014). Under these conditions not only are voluntary transfers highly unlikely, but mandatory ones remain vulnerable to legal challenge under human rights claims. Numerous reports by Amnesty International (2014), Human Rights Watch (2015), and the UK (2013) and United States governments (2014) attest to widespread overcrowding, violence and inadequate living standards. Constitutional protections have also only been minimally successful, as the vast majority (around three-quarters) of prisoners are held without sentence, some of them for many years at a time. According to the US State Department,

Prison and detention center conditions remained harsh and life threatening. Prisoners, a majority of whom had not been tried, were subject to extrajudicial execution, torture, gross overcrowding, food and water shortages, inadequate medical treatment, deliberate and incidental exposure to heat and sun, and infrastructure deficiencies that led to wholly inadequate sanitary conditions and could result in death. Reports indicated guards and prison officials extorted inmates or levied fees on them to pay for good, prison maintenance, and prisoner release. In some cases female inmates faced the threat of rape. Female prisoners pregnant at the time of incarceration gave birth to and raised their babies in prison. (US State Department, 2014: 6)

In a bid to circumvent the legal constraints such matters placed on their

\footnotetext{
${ }^{6}$ For more details see the full text of the Constitution of the Federal Republic of Nigeria, 1999. Available at: http://www.nigeria-law.org/ConstitutionOfTheFederalRepublicOfNigeria.htm
} 
ability to send prisoners back to Nigeria, the British government has invested in multiple criminal justice initiatives from human rights training for correctional officers and the police, to funding a whole new prison wing in Kirikiri prison, Lagos. If the Nigerians could not reform their criminal justice system, the British would do it for them. In what turned out to be a premature announcement, ${ }^{7}$ then chief Executive of the UK Border Agency, Lin Homer explained the situation to Parliament in 2009: "We are in negotiations with Nigeria to help them establish better prison conditions ... it is about helping them generate a structure that can cope. We are prepared to invest if that would enable us to send people home" (Homer as reported in Travis, 2009).

In fact, the mandatory transfer agreement was not signed for another five years (FCO, 2014, 2015). ${ }^{8}$ So, too, it turned out, it did not apply to all Nigerians in British prisons. In contrast to the British High Commission in Abuja which proclaimed that the PTA "will allow Nigerians who commit crimes in the United Kingdom, and Britons who commit crimes in Nigeria, to serve their sentences in their own country, where they can be properly prepared for release into the community in which they will live following their release" (British High Commission Abuja, 2014), the Explanatory Memorandum to the Treaty was more precise. "The consent of the sentenced person [to transfer] is not required", this document set out, "when that person is subject to an order for expulsion deportation or removal" (Wright, 2014: 1). Only those under Immigration Act powers in Britain, in other words, are subject to mandatory repatriation to Nigeria.

Notwithstanding the expansive nature of the UK Borders Act 2007 rule for mandatory deportation, two years since the agreement was signed, it is unclear whether Nigeria has received a single transfer. Instead, local reports suggest, the new wing of Kirikiri prison is being used for local prisoners. ${ }^{9}$

It is not only in the sphere of criminal justice that repatriation has been difficult to arrange. In late 2015 the British and Nigerian press reported critical comments from the Nigerian High Commissioner about British expulsion policies in general. According to Olukunle Akindele Bamgbose, the acting high commissioner to the UK, "the embassy was being asked to help remove people who were sick, had immigration appeals outstanding, had no ties to Nigeria, after living for many years in the UK and who in some cases were not even Nigerian" (cited in Grant and Wheeler, 2015).

Attempts to determine the reasons for the delay in transferring prisons have been unsuccessful. Yet, interviews I conducted with civil servants in 2014 suggest that the international agreement was beset by problems from the beginning as British delegations were met with suspicion and antagonism. Their role as former colonial masters was explicitly mentioned and critiqued. Some felt ridiculed. Their Nigerian counterparts, these civil servants allege, attended meetings irregularly, making it difficult to build personal ties. Meetings were

\footnotetext{
${ }^{7}$ According to a 2011 article in The Telegraph, drawing on WikiLeaks cables, the 2009 plans for the new prison were derailed when the UK refused to drop corruption charges against a member of the ruling party (Blake, 2011).

${ }^{8}$ It was signed on 9 January 2014 , entering into force nine months later.

${ }^{9}$ Whereas colleagues in the Nigerian NGO, PRAWA (personal correspondence) claim that nobody has been sent back, the security minister of Jamaica is cited referring to one man (Bunting, as cited in The Gleaner, 6 October 2015).
} 
cancelled. Different people were sent than were expected. There were also tensions within the British delegation. Those in the Home Office believed they were more motivated to pursue the agreement than their colleagues in the FCO. Different cultural practices were hard to reconcile. From the perspective of those familiar with the immigration detention system in Britain, the FCO were overly concerned with diplomacy. Their goals were not quite the same.

All told, the official rhetoric about British influence in Nigeria seems to have been distinct from the reality. Yet, the government remains resolute in its desire to expel, setting aside ongoing funds "to support prison reform in Nigeria and the return of prisoners from the UK to Nigeria" (Wright, 2014: 3). So, too, despite little evidence of the success of the Nigerian PTA or the training and reform programs, Britain announced in 2015, that it would fund a new prison in Jamaica under similar terms.

\section{Jamaica}

Britain has been trying to persuade the Jamaican government to sign a mandatory prison transfer agreement for nearly a decade. As they did in Nigeria they have invested considerable sums through the RRF in local correctional practices, funding training programs in a series of Jamaican penal establishments. From 2010, they have also contributed financially to the NGO, the National Organisation for Deported Migrants (NODM).

An official document from 2015 lists the achievements of their Rehabilitation and Reintegration Program (RRP) from 2008 to 2014. In it, the British High Commission in Kingston makes clear that migration control and punishment are interconnected. At a cost of $£ 4.6$ million over the six-year period, the RRP

financed a wide range of projects to assist Jamaican Nationals deported from the UK settle back into life in Jamaica and rehabilitate local ex-offenders through two primary outcomes;

1. The provision of adequate and appropriate support services to reintegrate and rehabilitate deportees and immigration offenders

2. Improve effective management of the prison population by the Department of Correctional Services.

The brief handout is one of the few sources of information, other than the High Commission's blog 10 about British policies in Jamaica. It reveals considerable and detailed involvement. The UK High Commission assisted the Jamaican Department of Correctional Services (DCS) in a range of operational matters including "business planning, implementing management frameworks, conducting audits and completing prison inspections." They also funded a series of prison regimes "vocational skills training, literacy programmes and sports initiatives", while improving procedures "to handle incidents such as fire, security, suicide and self-harm. Britain also paid to "improve the use and

10 See for example, 'Coming home to Jamaica'.

http://blogs.fco.gov.uk/ajordanwest/2013/02/19/coming-home-to-jamaica/ 
effectiveness" of non-custodial matters like community service orders and to increase the "capacity of the parole board to review and supervise cases."

The High Commission was equally busy in supporting deportees and their removal from the UK. British taxes "improved procedures to safely and securely receive and process returnees at both international airports" and to "transport [them] from the airport". The High Commission paid for "emergency accommodation", "help in finding family members" and "assistance in clearing personal goods from customs." As they did in prison they funded "training in vocational skills including barbering, cosmetology and IT." Finally, the list ends, with "Counselling and support."

Until recently, such small-scale interventions were all that the UK had managed to achieve. The Jamaican government was adamantly opposed to a mandatory PTA. In 2014 their Prime Minister made clear that the responsibility for dealing with those who broke the law rested with the sovereign state where the crime occurred. Yet, just one year later, on 30 September 2015, during a visit to the island state, Prime Minister David Cameron announced a breakthrough. Eight years after the drafting of the original voluntary agreement, he had persuaded the Jamaican government to take back at least some of their citizens serving prison sentences in Britain without first requiring their consent. "More than 300 Jamaican prisoners serving time in British jails will be returned back to Jamaica to serve their sentence", after 2020, the press release broadcasted (Prime Minister's Office, 2015).

As in Nigeria, the British government has agreed to build a new prison in Jamaica, providing ' $£ 25$ million from the governments' existing aid budget to help fund the construction of a new 1500 bed prison" (Prime Minister's Office, 2015). This arrangement, the official statement noted, overcame "one of the sticking points in the negotiations which had been the conditions in existing prisons in Jamaica."

On the same day the British government publicized the new PTA, Cameron addressed the Jamaican Parliament, unveiling $£ 300$ million in new financial commitments to the Caribbean, that more than quadruple Britain's previous support, making the UK the largest donor to the region (Cameron, 2015). "As well as seizing opportunities together," Cameron urged,

we must both face up to big global challenges together as well. We face common security threats like drug-running, crime, gangs. Inevitably, the close links between the UK and Jamaica mean that criminal activity here also has reverberations in the UK - and vice versa. Our crime can affect you.... So I say let us do this together.

In case the ties between neoliberalism and punishment had escaped them, he went on to urge his Jamaican colleagues to: "Invest together. Grow together. Support development together. Tackle climate change together. If we do this now - as I passionately believe that we should - then we can keep our partnership strong now and for the next 100 years to come" (Cameron, 2015).

Two weeks after Cameron's announcement of an agreement with Jamaica, local media reports emerged suggesting matters were not so clear-cut. Many Jamaicans were opposed to the PTA. They were outraged about the refusal of the British government to pay slavery reparations. The Jamaican government was 
forced to respond. Peter Bunting, the Security Minister, announced, in Parliament that,

Unfortunately, communications from the UK government, which has been carried in British and local media, may have left an impression in the public mind that Jamaica has signed a prisoner transfer agreement. This is not the case.

The fact is, we have agreed to commence a process which may or may not result in a prisoner transfer. We have brought these inaccuracies to the attention of the British high commission locally and trust that it will be corrected. (Bunting as reported by Mason, 2015)

All they had signed was a non-binding Memorandum of Understanding.

Bunting's speech, which was reported in detail by Jamaican newspaper The Gleaner, crystallized the contested nature of these international agreements by revealing the paradoxical range of rhetoric that animates and constrains them. From human rights to economic pragmatism, Bunting offers a series of justifications - all of which minimized the pain of deportation and denied the scale of British intervention in Jamaican sovereignty.

Much of the initial public outcry over the PTA was caused by Cameron's refusal to consider paying slavery reparations. Bunting downplayed that connection, by pointing out that Parliament "has joined the call for reparatory justice" (Bunting as cited in The Gleaner, 6 October 2015). The Prisoner Transfer Agreement, he said, "had been on the table for about a decade, long before the recent round of reparations discussions," and should be considered separately (Bunting as cited in The Gleaner, 6 October 2015).

The problem was not a legacy of slavery, he urged, but a question of human rights. "Building a modern, maximum-security prison for this administration," Bunting asserted, "is first and foremost an issue of Human Rights for our inmates right here in Jamaica! It is about securing our global reputation by establishing correctional facilities that meet international conventions and standards." The current prisons, Tower Street Adult Correctional Centre and St. Catherine Adult Correctional Centre, built under British rule, "are literally falling apart. They are outdated and dilapidated with limited scope for rehabilitation, severely overcrowded, substandard and inhumane" (Bunting as cited in The Gleaner, 6 October 2015). He said that Jamaicans who castigated Britain for refusing to pay reparations but did not support the PTA were hypocritical: "We have traditionally shown little public sympathy for the incarcerated, with many of us believing that offenders should be punished and made to endure harsh conditions, arguably worse than what obtained on the plantations during slavery" (Bunting as cited in The Gleaner, 6 October 2015).

Having made the case for the PTA and the new prison in terms of human rights, Bunting turned to the language of economic and political pragmatism for those who remained unconvinced. Negotiations had been long and difficult. It was time to resolve the matter. Only those citizens "who would have being subject to deportation at the end of their sentences will be eligible for transfer to Jamaica." It was not as though these people would not be sent back. "There are 
hundreds of Jamaicans deported every year to Jamaica," Bunting reminded his audience, "having served prison sentences for drug related or violent offences in the USA or the UK, without the benefit of a structured reintegration process. Accelerating the return of a small percentage of these Jamaicans through a structured rehabilitation and reintegration process is a reasonable trade-off for a dramatic improvement in our prison conditions" (Bunting as cited in The Gleaner, 6 October, 2015).

Finally, this canny politician sought to reassure the public about the scale of operations. Not only does the PTA allow no more than 300 spaces in the new prison for returnees, but, "in reality," he noted, "the numbers are likely to be much less." In Nigeria, after all, "which is in its second year," the UK "has only transferred one prisoner so far with another 16 in process. Nigeria has a higher number of prisoners in UK prisons than Jamaica" (Bunting as cited in The Gleaner, 6 October, 2015). The mandatory PTA, Bunting concluded, is nothing to worry about.

\section{Humanitarianism in the shadow of colonialism: Rethinking punishment and sovereignty}

As this article has demonstrated, Britain plays an active role in the criminal justice systems of Nigeria and Jamaica. At least in Jamaica, through NODM, the British government is also keenly engaged in funding service provision for those whom they have expelled. In both places the legislative and policy framework conjoins migration control and criminal justice through humanitarian goals and rhetoric.

For some, these projects are nothing new. "I did not witness historical colonialism or new colonialism in Nigeria," Viviane Saleh-Hanna asserted in her study of Nigerian prisons:

I witnessed expansion and abstraction in who maintains the colonial status quo... They came dressed in Human Rights caps looking to reform and strengthen European criminal justice in Africa through foreign aid. They came dressed in police uniforms reinforcing a status quo that keeps poor people in prison. (SalehHanna, 2008b: 21).

In the prisons that the new wings and institutions would replace, connections to the past take other forms. As Nigerian criminologists Uche et al. (2015: 165) note dryly, the colonial-built prisons, where most people still reside, "were not designed for reformation or rehabilitation rather prisons were intended to be punitive." "Native" criminals during the colonial era were the subjects of intense control (Saleh-Hanna, 2008a).

In these arguments the shadows cast by colonialism on contemporary policy interventions can be detected. Colonialism reminds us why the British are in these places, as well as why their policies are not always greeted enthusiastically by those whom they claim (and may even wish) to assist. The same history reminds us why Nigerians and Jamaicans find themselves in prisons and detention centres throughout the UK, as they make up two of the biggest groups of migrants in the country (Hall, 2001). 
The international donor community has been pursuing "justice" as one of its key targets for at least a decade (Piron, 2005; Saleh-Hanna, 2008a; Agier, 2011). In the funding models of these agencies, penal power becomes intricately linked to humanitarianism; one of several outputs and measures of reform. Within a postcolonial locale like Lagos or Kingston, the sites and personnel being reorganized and redeveloped, as well as the goal of reform itself, are interdependent. As the speech by the Jamaican Security Minister made clear, human rights rhetoric and practices can justify the exercise of coercive state powers, even if their supporters wish it were otherwise (Bunting, 2015; see also Barker, in press; Aas and Gundhs, 2015; Fassin, 2007; 2011; Walters, 2011). The ease with which matters of security become recast or reimagined as questions of humanitarianism (and vice versa) suggests a close conceptual tie between the two. Penal humanitarianism, in other words, allows the expansion of sovereign power over familiar, racialized, subjects and places, reasserting control, or at the very least, reimagining it, in places where Britain once ruled.

\section{Conclusion}

As states around the world restrict the means of legal entry to their territory, they have also shored up mechanisms for enforcing exit and preventing return. These powers do not merely exist on a continuum but often directly intersect. In their offshore practices, states rely on, reinforce and link ideas of security, risk and punishment, with humanitarianism, belonging and development.

Such practices have a direct impact on the practices and impacts of punishment. A penal sentence no longer, if it ever did, is limited to the jurisdiction where it is passed. While this article has focused on British policies in former colonies, other examples could be cited, from Norway, where, since 2015, prisoners may serve out their sentences in a Dutch prison, to Spain, whose criminal codes requires convicted foreign nationals to spend only a fraction of their sentence in the host country. In them all, punishment meted out 'at home' influence places and people 'abroad'. Penal expertise and practice are not contained within a nation state, but rather practitioners, policy makers, and other experts, travel the globe, implementing 'reforms' originally designed in one place in another.

On the one hand, these initiatives suggest that, in detaching from the nation state, and stepping outside the boundaries of the criminal justice system penal power has become more expansive and fluid. In this expansion penal power is often greatly aided by the elision of race, citizenship, and belonging, qualities made plain in the postcolonial setting of these programs. On the other hand, however, this article has highlighted numerous obstacles Britain faces in expelling those without the right to remain and securing its borders. In these cases, penal humanitarianism appears to rest on a more vulnerable form of sovereign power (Bosworth, 2008). Forcing people to go is difficult; persuading other countries to take them expensive.

The extension of penal power does not occur without resistance (Campesi, 2015). Not only is it difficult to remove unwanted offenders, who may have considerable ties in the UK, but as studies of deportees have shown, their home countries may be reluctant to take them back as they are often stigmatized and considered dangerous and disreputable (Golash-Boza, 2015; Bortherton and Barrios, 2011, Bowling, 2010). The mandatory transfer agreement with Nigeria, 
for now at least, is far more impressively coercive on paper than it is in practice. So, too, the passionate debate in Jamaica about British plans to fund a new prison suggests that the PTA will take some time to implement. Pastry-making classes for incarcerated young women or training in IT seem far removed from the heated debate over migration and belonging in the UK.

How to resolve these contradictions is not straightforward. Like other policies pertaining to border control and criminal justice, penal humanitarianism may well promise more than it can deliver. In its bid to influence policy abroad, Britain must balance its desires for migration control with its need to trade and influence. Penal power, in these instances, abuts other spheres of control. Outside its territory, Britain is not sovereign. At the same time, for those deported, or awaiting expulsion in immigration removal centres, the long reach of the British state can feel overwhelming (Bosworth, 2014).

Without overlooking the possibility that foreign-funded reforms will, sometimes, be welcome and even necessary (Jefferson and Gaborit, 2015), the sheer invisibility of these overseas programs and their lack of accountability raises questions. In the variety of programs, and the range of stakeholders and partner organisations, the British government is creating a form of governance that is both novel and familiar in which migration, punishment and development meld, and humanitarianism reactivates colonial pathways to identify, coerce and exclude (Agier, 2011). It is time to include such matters more squarely in our analysis of punishment. 


\section{References}

Aas, K. (2014). 'Bordered Penality: Precarious Membership and Abnormal Justice', Punishment \& Society. 16(5): $520-541$.

Aas, K. (2013). 'The Ordered and the Bordered Society: Migration Control, Citizenship and the Northern Penal State'. In K.F. Aas and M. Bosworth (Eds). The Borders of Punishment: Migration, Citizenship and Social Exclusion. Oxford: Oxford University Press. pp. $21-39$.

Aas, K. and M. Bosworth (Eds). The Borders of Punishment: Migration, Citizenship and Social Exclusion. Oxford: Oxford University Press.

Aas, K and H Gundhus. (2015). 'Policing Humanitarian Borderlands: Frontex, Humanitarianism and the Precariousness of Life.' British Journal of Criminology. 55(1): $1-18$.

Agier M. (2011). Managing the Undesirables: Refugee Camps and Humanitarian Government. London: Polity Press.

Aliverti, A. (2016). 'The Global Criminal Court.' In M. Bosworth, C. Hoyle and L. Zedner. (Eds). The Changing Contours of Criminal Justice. Oxford: Oxford University Press.

Amnesty International (2014). 'Welcome to Hell': Torture and Ill-Treatment in Nigeria. London: Amnesty International.

Barker, V. (in press, 2016). European Journal of Criminology.

Barker, V. (2013). 'Democracy and Deportation: Why Membership Matters Most' in Aas and M. Bosworth (Eds). The Borders of Punishment: Migration, Citizenship and Social Exclusion. Oxford: Oxford University Press. pp. 237 - 256.

Bhui, H.S. (2016). Criminology \& Criminal Justice.

Bhui, H.S., (2007), Alien experience: Foreign national prisoners after the deportation crisis. Probation Journal, 54 (4), 368 - 382.

Bosworth, M. (2014). Inside Immigration Detention. Oxford: Oxford University Press.

Bosworth, M. (2011). 'Deporting Foreign National Prisoners in England and Wales', Citizenship Studies. 15(5): 583 - 595.

Bosworth, M. (2008). "Border Control and the Limits of the Sovereign State". Social \& Legal Studies. 17(2): 199 - 215.

Bowling, B. (2010). Policing the Caribbean: Transnational Security Cooperation in Practice. Oxford: Oxford University Press. 
British High Commission Abuja (2014). 'UK - Nigeria Sign Compulsory Prisoner Transfer Agreement'. Available at: https://www.gov.uk/government/worldlocation-news/uk-nigeria-sign-compulsory-prisoner-transfer-agreement. Last accessed 21 September 2015.

Brotherton, D. and L. Barrios. (2011). Banished to the Homeland. New York: Columbia University Press.

Cameron, D. (2015). PM's Speech to the Jamaican Parliament, 30 September, 2015. Available at: https://www.gov.uk/government/speeches/pms-speech-tothe-jamaican-parliament

Campesi, G. (2015). 'Hindering the Deportation Machine: An ethnography of power and resistance in immigration detention, Punishment \& Society. 17(4): 427 $-453$.

Clayton, G. (2010). Textbook on Immigration and Asylum Law. Oxford: Oxford University Press.

Costello, C. (2015). 'Immigration Detention: The Grounds Beneath Our Feet', Current Legal Problems, 1-35.

Dauvergne, C. (2016). The New Politics of Immigration and the End of Settler Societies. Cambridge: Cambridge University Press.

DFID (2009). Written evidence submitted by the Department for International Development to the House of Commons International Development Committee, 13 October 2009. Available at: http://www.publications.parliament.uk/pa/cm200809/cmselect/cmintdev/840 /840we05.htm

Duff, R. (2010). 'A Criminal law for citizens.' Theoretical Criminology. 14(3): 293 309.

Elden, S. 2007 'Governmentality, Calculation, Territory', Environment and Planning D: Society and Space 25(3): 562-580.

Evans, 0. (2010). The Voluntary Assisted Return and Reintegration Program (VAARP) 2006: a process and impact assessment. London: Home Office. Available at:

https://www.gov.uk/government/uploads/system/uploads/attachment_data/fi le/116054/horr39-report.pdf Accessed 14 August, 2015.

Fassin, D. (2011). Humanitarian Reason: A Moral History of the Present. Berkeley, CA: University of California Press.

Fassin, D. (2007). 'Humanitarianism: A Nongovernmental Government', in M. Feher (ed.) Nongovernmental Politics, New York: Zone Books, 149-160. 
Garland, D. (1990). Punishment and Modern Society. Oxford: Oxford University Press.

Garland, D. (1996). "The Limits of the Sovereign State." British Journal of Criminology. 36(4): $445-471$.

Kaufman, E. (2015). Punish \& Expel: Border Control, Nationalism and the New Purpose of the Prison. Oxford: Oxford University Press.

Kaufman, E. (2013) in KF. Aas and M. Bosworth. (Eds). The Borders of Punishment. Oxord: Oxford University Press.

Kaufman, E. (2012) 'Finding Foreigners: Race and the Politics of Memory in British Prisons', Population, Space and Place, 18(6): 710-14.

Kaufman, E and M. Bosworth. (2013) 'Prison and National Identity: Citizenship, Punishment and the Sovereign State.' In D. Scott (Ed.). Why Prison? Cambridge: Cambridge University Press.

Kaufman, E. and S. Weiss. (2015). 'The Limits of Punishment.' In K. Reiter and A. Koenig (Eds). Extreme Punishment. London: Palgrave. pp. 32 - 49.

Golash-Boza, T. (2015). Deported: Policing Immigrants, Disposable Labour and Global Capitalism. New York: NYU Press.

Hannah-Moffat, K., and M. Lynch. (Eds.) (2012). 'Theorizing Punishment's boundaries', special issue of Theoretical Criminology. 16(2).

Hasselberg, I. (2016). Enduring Uncertainty: Deportation, Punishment and Everyday Life. London: Berghahn Books.

HMIP (2015). People in Prison: Immigration Detainees. London: HMIP. Available at: $\quad$ http://www.justiceinspectorates.gov.uk/hmiprisons/wpcontent/uploads/sites/4/2015/11/HMIP-Immigration-detainees-findingspaper-web-2015.pdf

Home Office, (2015a). Immigration Directorate Instructions: Deporting Non-EEA Foreign Nationals. Version 3.1, April 2015. London: Home Office. https://www.gov.uk/government/uploads/system/uploads/attachment_data/fi le/426906/Deport-non_eea_Foreign_Nationals.pdf

Home Office, (2015b). Country Information Guidance: Nigeria: Background Information including actors of protection and, internal relocation, 9 June 2015. London: Home Office. Available at: https://www.gov.uk/government/uploads/system/uploads/attachment_data/fi le/434067/Nigeria_CIG_Background_information_v1_0.pdf 
Home Office. (2013). Nigeria: Country of Origin Information (COI) Report. London: Home Office. Available at: https://www.gov.uk/government/uploads/system/uploads/attachment_data/fi le/310451/Nigeria_COI_report_2013.pdf

House of Commons Committee of Public Accounts (2015). Managing and Removing Foreign National Offenders. HC 708. London: HMSO. Available at: http://www.publications.parliament.uk/pa/cm201415/cmselect/cmpubacc/70 8/708.pdf

Human Rights Watch (2015). World Report 2014: Nigeria. Available at: https://www.hrw.org/world-report/2015/country-chapters/nigeria. Accessed 27 April, 2016.

IPPR (2013). Homecoming: The return and reintegration of irregular migrants from Nigeria. London: IPPR. Available at: http://www.ippr.org/files/images/media/files/publication/2013/04/Homeco ming_irregular_migrants_Nigeria_Apr2013_10661.pdf?noredirect=1 Accessed 14 August, 2015.

Jefferson, A. (2005). "Reforming Nigerian Prisons: Rehabilitating a 'Deviant' State." British Journal of Criminology. 45(4): 487 - 503.

Jefferson, A. and L. Gaborit (2015). Human Rights in Prison: Comparing institutional encounters in Kosovo, Sierra Leone and the Philippines. London: Palgrave.

Jones, T., and Newburn, T. (2002). 'Policy Convergence and Crime Control in the USA and the UK: Streams of Influence and Levels of Impact.' Criminology \& Criminal Justice. 2(2): 173 - 203.

Krutschnitt, C., Dirkzwager, A., Kennedy, L. (2013). 'Strangers in a Strange Land: Coping with Imprisonment as a Racial or Ethnic Foreign Inmate', British Journal of Sociology. 64(3): $478-500$.

Mujuzi, J. (2012). 'Analysing the agreements (treaties) on the transfer of sentenced (offenders/prisoners) between the United Kingdom and 22 Asian, African and Latin American countries.' European Journal of Crime, Criminal Law and Criminal Justice, 20(4): 377 - 414

Omale, D.J. (2014). 'Prisoners transfer agreement between Nigeria and the United Kingdom: A Critical Discourse.' Legal Studies. 1(1): 31 - 35.

O'Malley, P. (1999). 'Volatile and Contradictory Punishment', Theoretical Criminology. 3(2): 175 - 196.

Pennington, J., and B. Balaram. (2013). Homecoming: Return and Reintegration of Irregular Migrants from Nigeria. London: Institute for Public Policy Research. 
Piron, L-H. (2005). 'Donor Assistance to Justice Sector Reform in Africa: Living up to the New Agenda?' New York: Open Society Justice Initiative: 4 - 11. Available at: http://www.odi.org/sites/odi.org.uk/files/odi-assets/publications-opinionfiles/2309.pdf. Accessed 10 November 2015.

Poppleton, S., and L. Rice. (2010). Programmes and Strategies in the UK Fostering Assisted Return to and Reintegration in Third Countries. London: Home Office.

Prime Minister's Office (2015). Press Release: UK Signs Deal to send Jamaican Prisoners Home. Available at: https://www.gov.uk/government/news/uk-signsdeal-to-send-jamaican-prisoners-home

Prison Reform Trust. (2004). Forgotten Prisoners: The Plight of Foreign National Prisoners in England and Wales. London: PRT.

Ryan, B. and V. Mitsilegas, (Eds.). (2010). Extraterritorial Immigration Control: Legal Challenges. Amsterdam: Martinus Nijhoff Publishers.

Saleh-Hanna, V. (Ed.). (2008a) Colonial Systems of Control: Criminal Justice in Nigeria. Ottawa: Ottawa University Press.

Saleh-Hanna, V. (2008b). 'Penal Coloniality.' In V. Saleh-Hanna (Ed.). Colonial Systems of Control: Criminal Justice in Nigeria. Ottawa: Ottawa University Press.

Thomas, R. (2011) Administrative Justice and Asylum Appeals: A Study of Tribunal Adjudication, Oxford: Hart Publishing.

Tomczak, P. (2014). 'The penal voluntary sector in England and Wales: Beyond neoliberalism.' Criminology \& Criminal Justice. 14(4): 470 - 486.

Uche, I., Uche, O., Ezumah, N., Ebue, M., Okafor, A., Ezegebe, B. (2015). 'Effectiveness of Rehabilitation Programs in Nigerian Prisons: A Study of Perception of Inmates in Enugu Prison.' Mediterranean Journal of Social Sciences. 6(4): $164-170$.

US State Department. (2014). Human Rights Country Report 2013: Nigeria. Washington, DC: US State Department. Available at: http://www.state.gov/documents/organization/220358.pdf Accessed 214 August, 2015.

Van Zyl Smit, D. and R. Mulgrew. (2012). Handbook on the International Transfer of Sentenced Persons. New York: United Nations. Available at: https://www.unodc.org/documents/organized-

crime/Publications/Transfer_of_Sentenced_Persons_Ebook_E.pdf. Accessed 27 October 2015.

Walters, W. (2016). 'The Flight of the Deported: Aircraft, Deportation, and Politics', Geopolitics. 21(2): 435 - 458. 
Walters, W. (2011). 'Foucault and Frontiers: Notes on the Birth of the Humanitarian Border' in U. Bröckling, S. Krasmann and T. Lemke (Eds), Governmentality: Current Issues and Future Challenges, New York: Routledge, pp.138-164.

Warr, J. (2016). 'The Deprivation of Certitude, Legitimacy and Hope: Foreign National Prisoners and the Pains of Imprisonment.' Criminology \& Criminal Justice.

Zedner, L. (2013). 'Is the Criminal Law only for Citizens: A Problem at the Borders of Punishment?' in K. Aas and M. Bosworth (Eds.). The Borders of Punishment.

\section{Media Accounts}

BBC (2012). UK spent £3m last year to improve foreign prisons. 9 August, 2012. Available at: http://www.bbc.co.uk/news/uk-19191735. Last Accessed 4 December 2013.

Blake, H. (2011). 'WikiLeaks cables: Nigeria pressured UK to drop charges against politician.' The Telegraph. 4 February, 2011. Available at: http://www.telegraph.co.uk/news/worldnews/wikileaks/8303381/WikiLeakscables-Nigeria-pressured-UK-to-drop-charges-against-politician.html

Doyle, J. (2013). UK to pay for foreign jails in a bid to repatriate more prisoners. 26 April, 2013. Mail Online. Available at: http://www.dailymail.co.uk/news/article-2315548/UK-pay-foreign-jails-bidrepatriate-prisoners.html. Last Accessed 4 December 2013.

Chorley, M. (2013). 'Hundreds of Nigerian Prisoners to be sent home to serve out sentence under deal to ease pressure on UK jails.' 15 October, 2013. Daily Mail. Mail Online. Available at: http://www.dailymail.co.uk/news/article2460532/Hundreds-Nigerian-prisoners-sent-home-serve-sentence-deal-easepressure-UK-jails.html

The Gleaner. (2015). 'No prison deal yet, Bunting insists, Committee to First Consider. The Gleaner. 7 October 2015. Available at: http://jamaicagleaner.com/article/news/20151006/no-prison-deal-yet-bunting-insistscommittee-first-consider. Last Accessed 6 November 2015.

Grant, H., and Wheeler, J. (2015). 'UK pressures Nigeria to help Home Office increase deportations.' The Guardian Online. 19 November 2015. Available at: http://www.theguardian.com/uk-news/2015/nov/19/uk-pressures-nigeriahelp-home-office-deportations-embassy-immigration-crackdown

Holehouse, M. 'Pledge to free up UK jails sees just 17 EU prisoners sent home to serve time. 12 April 2014. The Telegraph. Available at: http://www.telegraph.co.uk/news/uknews/law-and-order/10761426/Pledge- 
to-free-up-UK-jails-sees-just-17-EU-prisoners-sent-home-to-serve-time.html. Last Accessed 21 September 2015.

Ijioma, E. (2013). Nigeria: UK Pays $£ 1$ Million to Transfer 534 Nigerian Prisoners Home. All Africa. 16 October 2013.

Available at: http://allafrica.com/stories/201310160515.html. Last Accessed 4 December 2013.

Iroegbu, S. and Oyedele, D. (2012). "Nigeria, UK Prisoners' Transfer Suffers Hitch." This Day. 16 August 2012. AllAfrica.com. Available at: http://allafrica.com/stories/201208270968.html Accessed 26 April 2016.

Jamaica Observer. (2015a). 'Reject UK’s £25-m prison deal, Young Jamaica Tells Govt.' in Jamaica Observer, 30 September 2015. Available at: http://www.jamaicaobserver.com/news/Reject-UK-s--25-m-prison-deal-Young-Jamaica-tells-Gov-t. Accessed on 6 November 2015.

Jamaica Observer. (2015b). 'Bunting: View prison deal as 'enlightened selfinterest'. Jamaica Observer. 6 November 2015. Available at: http://www.theguardian.com/politics/2015/oct/13/jamaica-denies-signing-ukdeal-repatriate-hundreds-prisoners-transfer. Accessed 6 November 2015.

Mason, R. (2015). 'Jamaica accuses Cameron of mis-representing prisoner transfer deal.' The Guardian. 13 October, 2015. Available at: http://www.theguardian.com/politics/2015/oct/13/jamaica-denies-signing-ukdeal-repatriate-hundreds-prisoners-transfer. Accessed 6 November 2015.

Oyedele, D. (2013). Nigerian Prisoners in UK Face Repatriation. This Day Live. 20 January 2013. Available at: http://www.thisdaylive.com/articles/nigerianprisoners-in-uk-face-repatriation/136940/ Last Accessed 4 December 2013.

Travis, A. (2009). Multimillion pound deal could send Nigerian prisoners home. The Guardian. 8 July 2009. Available at: http://www.theguardian.com/society/2009/jul/08/nigeria-prisoner-transferborder-agency. Last Accessed 4 December 2013.

Willsher, K. (2014). 'Migrant Arrests at Calais Double' The Guardian. 18 July 2014. Available at: http://www.cglpl.fr/2014/avis-relatif-a-la-situation-despersonnes-etrangeres-detenues/ Last Accessed 21 July 2014.

\section{Law}

Constitution of the Federal Republic of Nigeria, 1999.

FCO (2015). Agreement between the Government of the United Kingdom of Great Britain and Northern Ireland and the Government of the Federal Republic of Nigeria on the Transfer of Sentenced Persons. Treaty Series No. 26 (2015). Cm 913. 
FCO (2014). Agreement between the Government of the United Kingdom of Great Britain and Northern Ireland and the Government of the Federal Republic of Nigeria on the Transfer of Sentenced Persons. Nigeria No. 1 (2014). Cm 8791.

Return Fund, 2008-13. http://eur-lex.europa.eu/legalcontent/EN/TXT/?uri=URISERV:114570

\section{Bio}

Professor Mary Bosworth (Professor in Criminology, Fellow of St Cross College University of Oxford, concurrently Professor of Criminology, Monash University, Australia). Research interests include: immigration detention, punishment, race, gender and citizenship. She is author of Engendering Resistance: Agency and Power in Women's Prisons (1999, Ashgate); The US Federal Prison System (2002, Sage); Race, Gender and Punishment: From Colonialism to the War on Terror (2007, Rutgers University Press) co-edited with Jeanne Flavin, and Explaining US Imprisonment (2009, Sage), What is Criminology? (2010, OUP), co-edited with Carolyn Hoyle, The Borders of Punishment (2013, OUP), co-edited with Katja Aas, Inside Immigration Detention (2014, OUP) and The Changing Contours of Criminal Justice co-edited with Carolyn Hoyle and Lucia Zedner (2016, OUP), in addition to numerous journal articles and book chapters on prisons, punishment, race, gender and qualitative research methods. Mary is currently heading a five-year ERC Starter Grant on the intersections between criminology and border control, as well as a three year Leverhulme International Network on External Border Control. In Oxford she is Assistant Director of the Centre for Criminology and Director of the Border Criminologies Research Group. Mary is UK Editor-in-Chief of Theoretical Criminology, a co-editor of Routledge Studies in Criminal Justice, Borders and Citizenship, and a member of the editorial boards of Race \& Justice, the International Journal of Migration and Border Studies, and Clarendon Studies in Criminology at Oxford University Press. 